\title{
An Intersectionality-Based Policy Analysis of High Seas Policy Making Stagnation and
}

\section{Equity in United Nations Negotiations}

The American Academy of Social Work and Social Welfare's Grand Challenges for

4 Social Work call on social workers to "create social responses to a changing environment" by

5 addressing the socioeconomic impacts of environmental challenges with a specific emphasis on

6 "advocacy to elevate public and policy attention to the social and human dimensions of

7 environmental change" (Kemp \& Palinkas, 2015, p. 3). However, inequitable governance

8 structures perpetuate the socioeconomic disparities created by environmental changes-

9 threatening achievement of the United Nations' Sustainable Development Goals [SDGs]. As a

10 result, social workers need to move beyond using policy to address environmental inequities, and

11 critique the structures used for global governance of shared natural resources. One pertinent

12 example is the governance of the high seas, or the ocean's international waters beyond a singular

13 country's jurisdiction, under the 1982 United Nations Convention on the Law of the Sea

14 [UNCLOS].

15 One of the ocean's most pressing social-ecological challenges is marine fish stocks'

16 continued decline, with $33.1 \%$ of stocks classified as overfished (i.e., fished beyond sustainable

17 levels) in 2015, a 1.4\% increase from 2013 (Food and Agriculture Organization (United Nations)

18 [FAO], 2018). These changes are primarily perpetrated by increasing fishing pressures, driven by

19 consumption demands predicated on greater demand for exotic fish products (e.g., sushi), trade

20 globalization, human population growth, and increasing scientific evidence of fish's health and

21 nutritional benefits (FAO, 2018). And, while stocks in developed countries' coastal waters

22 showed some rebounds, these gains were offset by further decreases in developing countries'

23 stocks (FAO, 2018). The persistence of these declines is problematic: Though poorer states lack 
24 the capacity to fish on the high seas, and no artisanal or subsistence fishing occurs that far from

25 shore, approximately $54 \%$ of low-income, fish-reliant states depend on species that straddle

26 and/or migrate between territorial waters and the high seas (Teh et al., 2016). Of the 10 million

27 tons of fish caught on the high seas, less than $1 \%$ contains species found exclusively in the high

28 seas (Sumaila et al., 2015).

29 Because of this straddling, high seas overfishing impacts reverberate through populations

30 not engaged in the activity. Specifically, high seas overfishing contributes to coastal stock

31 depletions - threatening many of the world's most vulnerable populations. While 3.1 billion

32 people, or more than $40 \%$ of the world's population, rely on seafood as their primary protein

33 source, in most coastal developing countries, marine fish constitute more than $50 \%$ of dietary

34 protein intake (FAO, 2016). Approximately $90 \%$ of small-scale (e.g., subsistence and artisanal),

35 marine capture fishers worldwide (or an estimated 22-26 million impoverished people) live in

36 coastal developing countries where few alternative livelihood activities exist (Teh \& Sumaila,

37 2013). Therefore, high seas governance is a social justice issue of relevance to ecosocial work.

38 This paper offers an Intersectionality-Based Policy Analysis [IBPA] (Hankivsky, 2012) of

39 United Nations [UN] policymaking related to the high seas, including an empirical analysis of

40 committee structures and voting patterns to support this conceptual framework, and an

41 examination of the differential impacts of high seas policymaking on marginalized global

42 populations. The IBPA framework evaluates how intersecting identities and characteristics of a

43 population - here, global states - perpetuate inequities and privileges in policy problems,

44 processes, and responses. It is based on the premise that reducing marginalized populations to a

45 singular identity perpetuates oppression (Hankivsky, 2012). UNCLOS, a macro policy focusing

46 on parties to the convention, ascribes a singular identity to all parties - a member state. This 
47 practice inhibits equity by ignoring the plurality of characteristics that formulate each state's

48 identity and how these characteristics interact to influence the state's behaviors and participation

49 in international high seas policy decision-making processes. Considering this intersectionality is

50 also imperative to gaining a more complex understanding of the power relationships between

51 states and how specific characteristics (e.g., major economies) may be more valued, maintaining

52 unequal power distributions throughout the UN system. The paper concludes with

53 recommendations for transforming the problem and the policy process with a focus on equitable

54 outcomes and a discussion of ecosocial work's role in global policymaking.

55 High Seas Policy Making Under the UN Convention on the Law of the Sea (UNCLOS)

56 Signed in 1982, UNCLOS attempted to create a comprehensive and unified governance

57 regime for Earth's oceans to curb national sovereignty claims (Dieter, 2014). It demarked

58 distinct maritime zones; ascribed national authority (and restrictions) over territorial waters,

59 contiguous zones, and exclusive economic zones; and classified the high seas, “...all parts of the

60 sea that are not included in the exclusive economic zone, in the territorial sea or in the internal

61 waters of a State, or in the archipelagic waters of an archipelagic State" as international waters

62 beyond national jurisdiction and therefore subject to governance exclusively by UN international

63 and multilateral laws and policies (UN, 1982, Part VII, Art. 86, para. 1). Building upon the

64 ideology the high seas were a common-pool resource and thus, access should be open to all

65 states regardless of geography, Article 87 advanced high seas' "freedoms" (UN, 2017a).

When states assented to UNCLOS, technology limitations prohibited or limited most high

67 seas activities, including fishing, making strict high seas protections less important in the original

68 negotiations (Visbeck et al., 2016). These technological limitations also constrained the scientific

69 knowledge about the high seas available during negotiations. As technological capacity to 
70 exploit high seas resources and scientific understanding simultaneously grew, the scientific

71 community began advocating for new policies to address UNCLOS' deficiencies. Since the

72 1990s, UN entities have enacted a series of international and regional policies to address

73 UNCLOS' gaps and more consistently apply UNCLOS' regulations to increase the achievement

74 of its objectives. However, these measures are restricted by UNCLOS' superseding authority and

75 have primarily relied on voluntary, non-binding instruments that lack formal enforcement

76 procedures. Benefits of these soft laws can include greater consensus and international

77 cooperation, and easier implementation since they do not depend on each member state's own

78 ratification processes; however, their effectiveness can be hindered by a lack of political will to

79 ensure compliance, which may conflict with the state's economic interests (Visbeck et al., 2016).

80 On December $24^{\text {th }}, 2017$, the UN adopted a resolution to convene an intergovernmental

81 conference to negotiate a new "internationally legally binding instrument under UNLCOS on the

82 conservation and sustainable use of marine biological diversity of areas beyond national

83 jurisdiction" (UN, 2017a, para. 12). This vote was the culmination of more than a decade of

84 negotiations, and the work of four preparatory meetings convened between 2016 and 2017 to

85 address scientific concerns of inadequate high seas protection and regulation (High Seas Alliance

86 [HSA], 2017). While rhetoric around the length and stagnation of preliminary negotiations

87 focused on tensions between conservation and management for maximum economic and

88 sustainable exploitation, including that espoused by delegates from wealthier states (UN, 2017b),

89 less attention was afforded to the underlying power differentials between UN member states.

90 Building on SDG 14, "Life Below Water," the upcoming internationally binding

91 instrument negotiations present an opportunity to formally institutionalize the SDG's

92 environmental, economic, and social equity aims through more protection oriented high seas 
93 regulations (Editorial, 2018). However, socioeconomic and political inequities perpetuated by

94 international policy making processes, including the recent UNCLOS preparatory meetings, may

95 undermine the SDGs' social justice aims. Scholars have already noted the divergent positions

96 between developed and developing countries in the original UNLCOS negotiations (e.g.,

97 Stevenson \& Oxman, 1994) and NGOs have critiqued UNCLOS and its subsequent mechanisms

98 for regulatory shortcomings and gaps (e.g., Gjerde, Currie, Wowk, \& Sack, K., 2013). However,

99 many critiques have not considered power differentials potentially entrenched in the UN system,

100 and if existent, how they may influence state engagement or lack thereof in international policy

101 making. The failure to create and implement binding laws more strictly regulating the high seas

102 serves the economic interests of privileged states (i.e., industrialized and large/major economies)

103 while potentially threatening the security of vulnerable states (i.e., small economies, Least

104 Developed Countries [LDCs] and Small Island Developing States [SIDS]). This power dynamic

105 must be understood and remedied to advance greater equity in the new treaty.

106 Current Representations of the Problem

107 UNCLOS and the subsequent UN Straddling Fish Stocks Agreement [UNFSA]

108 established intergovernmental regional fisheries management organizations [RFMOs] as the

109 primary high seas governance mechanism (UN, 1995). Any state with a financial or practical

110 interest in the region's fisheries and stock management can be a member of a RFMO, and states

111 can, and do, belong to multiple RFMOs. Existing critiques of UNCLOS and its subsequent

112 multilateral and regional policies have often centered on RFMOs' ineffectiveness in maintaining

113 productive high seas fish stocks. Reasons for this ineffectiveness include diversity and range in

114 directives amongst RFMOs; the production and dissemination of inaccurate catch and by-catch

115 data; member state favoritism; inadequate performance review criteria; a lack of transparency 
116 around decision-making processes; enforcement and compliance challenges; exploitation of flag

117 state jurisdiction; inconsistencies in confronting illegal, unreported, and unregulated (IUU)

118 fishing; and political interference suppressing scientific concerns (Dieter, 2014; Gjerde et al.,

119 2014). The use of voluntary and non-binding international and multilateral instruments has failed

120 to address these RFMO problems, primarily because RFMOs can fail to implement

121 recommendations with impunity (Gjerde et al., 2013). Though itself binding, UNCLOS also

122 lacks global compliance mechanisms, instead relying on the right of exclusive jurisdiction for

123 flag states—a mechanism with consistently abused loopholes (Dieter, 2014).

124 The representation of high seas overfishing resulting from fragmented RFMO governance

125 schemes is important and scientifically justified. However, by constructing the policy problem

126 around the aggregate collection of RFMO party states, it is possible to overlook interactions and

127 power differentials between member states that could influence RFMO effectiveness, and deflect

128 responsibility away from the self-interests of powerful states onto the more collective RFMOs.

129 Differential Impacts

130 Empirical evidence suggests UNCLOS and RFMOs are failing in their responsibilities to

131 protect and ensure sustainable fish stocks, with high seas fish stocks continuing to decline as a

132 result of overfishing (Cullis-Suzuki \& Pauly, 2010). Due to prohibitive costs and technological

133 needs, most high seas fishing is monopolized by commercial vessels unsustainably subsidized by

134 a few wealthy states (e.g., the United States, Russia, and Japan) and 10 states account for more

135 than $60 \%$ of high seas fish catch (Sumaila et al., 2015). However, poorer, fish-reliant states will

136 be disproportionately impacted by straddling and/or migrating fish stocks overfished on the high

137 seas (Teh et al., 2016; White \& Costello, 2014). Because overfishing's social effects are

138 mediated through economic structures, even if fish stocks collapse, it is likely populations in 
139 wealthier states will have access to alternative food and nutrition sources, and comparatively 140 little of the populations in these states rely on fishing as their sole livelihood. However, for the

141 human populations in poorer, fish-reliant states, alternative livelihoods and nutritious food

142 sources are severely limited. The human population is expected to reach 9.6 billion people by

1432050 , with the majority of this increase anticipated in urban areas of coastal states with pre-

144 existing high food insecurity rates, further pressuring fish stocks that are viewed as an essential 145 resource for poverty alleviation and the attainment of the SDGs (FAO, 2018).

146 Further, RFMOs are responsible for their funding, leading to notable disparities between 147 organizations (Global Ocean Commission [GOC], 2013). The 11 largest RFMOs (four of which 148 exclusively manage tuna stocks — a species primarily fished and consumed by wealthy states)

149 receive approximately USD \$28 million per year collectively from large repositories such as the 150 European Maritime and Fisheries Fund (funded by EU member states). Even amongst the 11, 151 funds are disproportionately allocated to RFMOs exclusively managing tuna stocks. In 2013, the 152 Inter-American Tropical Tuna Commission [IATTC] received over USD \$6.3 million (the top 153 funded of the 11 largest RFMOs), while the South Pacific Regional Fisheries Management 154 Organization [SPRFMO] received only USD \$706,900 (the least funded of the largest 11 155 RFMOs) (GOC, 2013). In 2014, Japan, Taiwan/China, and the United States were three of the 156 four largest contributors to the tuna catch, and had a vested interest in contributing funds to tuna 157 RFMOs (Galland, Rogers, \& Nickson, 2016). Indeed, there are suggestions the allowable catch 158 limits established by RFMOs are politically influenced through states' donations (Galland et al., 159 2016).

160 Current Policy Responses 
After a decade of negotiations (HSA, 2017), UN General Assembly [UNGA] Resolution

$16269 / 242$ in 2015 called for the creation of an international, legally binding instrument under

163 UNCLOS to enhance biodiversity protection and ensure sustainable high seas' use (UN, 2015b).

164 Prior to beginning negotiations in the UNGA though, four preparatory meetings were convened

165 between 2016 and 2017 to draft text for a future treaty, offering an opportunity for economically

166 powerful states (e.g., Russia and the United States) to undermine and dilute language regarding

167 stricter proposed regulations before full treaty negotiations even began. For example, to achieve

168 consensus and appease industrialized states with commercial interests in high seas' resource

169 exploitation, the recommendations were divided into two groups: an A-section, characterized by

170 "convergence" among states; and, a B-section, characterized by "divergence." The primary

171 divisions were about the potential treaty's institutional structures, with developing countries,

172 "calling for an increasingly ambitious and articulated international architecture, with multiple

173 funds and overview and support mechanisms" while developed countries, "were worried about

174 the costs involved, advocating for a light institutional structure" (International Institute for

175 Sustainable Development [IISD], 2017, p. 20).

176 A SIDS' special case principle including equal engagement, special consideration, and

177 "preferential treatment and access procedures for SIDS and LDCs" and the retention of language

178 from UNFSA about special requirements for SIDS and LDCs and avoiding "disproportionate

179 burdens" was supported by Alliance of Small Island States [AOSIS], the African group, LDCs,

180 and the Pacific Small Island Developing States [PSIDS] (IISD, 2017, p. 9). The United States,

181 Japan, Australia, European Union, Canada, and Switzerland all vocalized opposition. Due to lack

182 of consensus, the special requirements and disproportionate burden language were included in

183 the B-section, and the SIDS special case principle was excluded (IISD, 2017). Moreover, the 
184 UNGA was not required to convene an intergovernmental conference for the negotiation of a

185 new binding treaty, and though it did, the draft text provided by the $4^{\text {th }}$ Preparatory Commission

186 was "without prejudice to states" positions during negotiations" (IISD, 2017, p. 4).

187 The final draft text also suggests industrialized, large economy states may be unwilling to 188 abandon UNCLOS' "freedom of the seas" principle regarding fish commodities. Though the G-

18977 (i.e., a group of 77 developing states) wanted to include language identifying the potential 190 treaty's overarching objective as "long-term, sustainable use and conservation," the "long-term"

191 descriptor was dropped due to Russia's demands, and instead language about reinforcing

192 effective implementation of UNCLOS was included (IISD, 2017, p. 6-7). Thus, there should be

193 concerns the new instrument will not significantly depart from previous policy. This divergence

194 between lower and higher income states has also occurred in historical UNCLOS negotiations,

195 such as those concerning the management of seabeds - another resource which poorer states

196 lacked the capacity to exploit - and the common heritage of [hu]mankind (CHM) (See Stevenson

197 \& Oxman, 1994; Nordquest, Rosenne, \& Kraska, 2011; and Guntrip, 2003).

A 2009 analysis of social-ecological systems approaches in multilateral environmental

200 treaties and negotiations found "questions of power, conflicts, and inequalities" were ignored

201 (Hornborg, 2009, p. 238), serving powerful states' economic interests. Further, historically

202 powerful states have been able to imbue policy development with their self-sovereignty ideology

203 by wielding their economic power (Dreher, Nunnenkamp, \& Thiele, 2006). This sub-analysis,

204 conducted within the context of the IBPA framework, explored the likelihood that UN power

205 structures facilitate inequities in marine policy making and other international policy making

206 processes by providing an empirical analysis of UN organ structure and composition which maps 
207 relationships between the economic characteristics of states and their representation in UN

208 organs. The founding hypothesis is that state economic power is a predictor of representation in

209 UN organs, and subsequently, influence on UN policy making, despite the establishing principle

210 that, "The United Nations shall place no restrictions on the eligibility [of member states] ... to

211 participate ... in its principal and subsidiary organs" (UN, 1945, Chap. 3, Art. 8).

\section{Methodology}

213 Current and historical UN membership data was procured from official UN websites,

214 including websites for each organ (General Assembly of the United Nations, 2017; International

215 Court of Justice [ICJ], 2017; UN, 2016; UN Economic and Social Council, 2017; UN Secretary

216 General, n.d.; UN Security Council, n.d.). Gross domestic product [GDP], LDC, SIDS, and low-

217 income country data was then overlaid upon UN membership data. The list of LDCs and SIDS

218 was retrieved from the UN Office of the High Representative for the Least Developed Countries,

219 Landlocked Developing Countries and Small Island Developing States (2017). Both the GDP

220 rankings for 2016 and the list of low-income countries (i.e., the World Bank's comparable LDC

221 designation) were obtained from the World Bank (2017). The World Bank ranked 185 of the 193

222 UN member states in 2016. Andorra, Eritrea, North Korea, Libya, Monaco, San Marino, Syria,

223 and Venezuela did not make GDP data available, and thus were excluded. The authors divided

224 the list of 185 states into quartiles. Each quartile included 46 states, with the exception of the $2^{\text {nd }}$

225 quartile ( $49^{\text {th }}$ to $25^{\text {th }}$ percentile), which included 47 states. Tajikistan, ranked $139^{\text {th }}$ of UN

226 member states, was the $47^{\text {th }}$ state included in the $2^{\text {nd }}$ quartile. GDP was selected as the

227 economic/wealth indicator since it is a measure of market activity frequently used to distinguish

228 economy size and often used in policy making. While it fails to measure human well-being and

229 is limited in its ability to represent informal economic activity, the IBPA analysis was based on a 
230 hypothesis that the UN favors highly developed states with large economies despite its founding

231 principle of "sovereign equality" for all member states (UN, 1945, Chap. 1, Art. 2(1)).

232 Results

233 Six principal organs comprise the UN system: The General Assembly [UNGA], Security

234 Council [UNSC], International Court of Justice [ICJ], Economic and Social Council [ECOSOC],

235 Trusteeship Council, and the Secretariat. The UNGA is the only organ requiring representation

236 for all UN member states, and is divided into five regional groups functioning as voting blocs.

237 With five permanent member states (China, France, Russia, the United Kingdom, and the United

238 States) and 10 additional rotating member states, the UNSC is widely considered the most

239 powerful organ. The UNSC's five permanent member states are also guaranteed representation

240 on the ICJ, comprising one-third of the court's 15 seats, and were the only member states

241 represented on the Trusteeship Council, suspended in 1994. The ECOSOC, which is the primary

242 international body for sustainable development has 54 members. The Secretariat is led by the

243 Secretary-General, elected from one member state.

244 Of the United Nations Security Council's five permanent members, the United States is

245 ranked first in GDP, China second, the United Kingdom fifth, France sixth, and Russia $12^{\text {th }}$.

246 While the other 10 UNSC members rotate, $66 \mathrm{UN}$ member states have never served on the

247 council (UNSC, n.d.). Of those 66 members, five were not ranked by GDP. An examination of

248 the remaining 61 states determined only two (3.0\%) states are in the upper quartile globally for

249 GDP, while $34(55.7 \%)$ are ranked in the lower quartile (Fig. 1). Though 31 of the $47(66.0 \%)$

250 states classified by the UN as a LDC have served on the UNSC, only 8 of the 27 (21.6\%) states

251 classified as a SIDS have served. Only one of the eight states classified as both, Guinea-Bissau,

252 has filled a membership position. Though non-permanent members are selected from each of the 
253 five regional groups, states' candidacies for a non-permanent position must first be endorsed by

254 their regional bloc. Once endorsed, they then must be elected by a two-thirds vote in the UNGA.

255 States serve a two-year term, and can be re-elected. This system eschews equity for political

256 maneuvering and favoritism. For example, since 1966 when the current regional groups were

257 configured, only 23 (41.8\%) of the Asia-Pacific Regional Group's 55 member states have been

258 non-permanent members of the UNSC, with one state - China — serving as a permanent member.

259 Further, 12 of the 23 states have served multiple times, including Japan, which has represented

260 the Asia-Pacific group 10 times since 1966 for a total of 20 years. None of the Asia-Pacific

261 group's SIDS have been represented on the council.

All parties to the Statute of the Court (i.e., all 193 UN member states and some observer

264 states) can nominate a candidate for the International Court of Justice (ICJ), though the state does

265 not advance the candidate. Instead, members of the Permanent Court of Arbitration, who are

266 designated by the state, will propose the nominee. For states that are not members of the

267 Permanent Court of Arbitration, a congruent process is established to propose candidates. To be

268 elected, the nominee must then receive a majority two-thirds vote in concurrent voting in the

269 UNGA and the UNSC. Only 47 of the 193 (24.3\%) UN member states have ever been

270 represented on the ICJ, including the five seats continuously held by the UNSC permanent

271 members. Of those 47 members, 26 (55.3\%) are ranked in the upper quartile of GDP; whereas,

272 only three (6.4\%) are ranked in the lower quartile (Fig. 2). Five (10.6\%) judges have been

273 appointed from one of the 47 LDCs. In February 2015, Judge Patrick Lipton Robinson from

274 Jamaica was appointed to the court, marking the first time a SIDS was represented. No judges

275 have been appointed from one of the eight states identified as a LDC and SIDS. 
[Insert Figure 2 here]

The Economic and Social Council's [ECOSOC] 54 member states are elected for three-

278 year terms by the UNGA. Currently a set number of seats is allocated to each regional group:

279 African Group (14), Western European and Other States Group (13), Asian Group (11), Latin

280 American and Caribbean Group (10), and Eastern European Group (6). While historical

281 membership data was unavailable, an analysis of the current 54 members determined that only

282 eight LDCs are represented on the ECOSOC, comprising $14.8 \%$ of the ECOSOC body and just

$28317.0 \%$ of all LDCs. Half of the African Group's representatives are LDCs. However, when

284 examining GDP rankings, 26 of the $52(50 \%)$ ranked member states are in the upper quartile,

285 while only six (11.5\%) are ranked in the lower quartile (Fig 3). Only two of the $54(3.7 \%)$ total

286 members are SIDS, resulting in 5.4\% of all SIDS being represented; yet, all five permanent

287 UNSC members are also members of the ECOSOC. None of the eight states classified as both a

288 LDC and SIDS are represented. Historical data on the ECOSOC president indicates that 37 states

289 have been represented. One is unranked by GDP (Venezuela) and one country no longer exists

290 (Yugoslavia). Of the remaining 35 presidential member states, 19 (54.3\%) are ranked in the

291 upper quartile for GDP, and zero are ranked in the lower quartile (Fig. 3). Three LDCs have been

292 represented, and only one SIDS (Jamaica), which is also classified as a LDC. The Secretary-

293 General leads the Secretariat and is "appointed by the General Assembly on the recommendation

294 of the Security Council" (UN Secretary General, n.d., para. 1). The current Secretary-General is

295 from Portugal, and the previous eight Secretary-Generals represented Korea, Ghana, Egypt, Peru,

296 Austria, Myanmar, Sweden, and Norway. Myanmar is the only LDC to produce a Secretary-

297 General, and also has the highest ranked GDP of any LDC, ranking $69^{\text {th }}$ out of the 193 member 
states. No Secretary-General has been appointed from a SIDS; yet, four out of nine (44.4\%) have been appointed from highly developed, Western states.

While every member state is equally represented in the UNGA's body, the body annually

elects a president for a one-year term. Candidate nominations rotate between the five regional groups, with the five UNSC permanent members excluded. A total of 71 states have been represented by the presidency, and Argentina is the only state represented twice. Of the 71 presidential member states, three are unaccounted for in GDP rankings, resulting in 68 states for analysis. The UNGA leadership reflects the same dichotomy as other UN organs as 31 states $(45.6 \%)$ are ranked in the upper quartile for GDP; whereas, five states $(7.3 \%)$ are ranked in the

308 lower quartile (Fig. 4). Only five (10.6\%) presidents have been elected from one of the 47 LDCs, 309 and only three (8.1\%) from the 37 SIDS. No president has been elected from any of the eight 310 member states classified by the UN as both a LDC and a SIDS. The one vote per country UNGA

311 rule positions less developed states with small economies as equal members; however, these

312 states may still be positioned as former colonies through the exchange of money and power for

313 votes. In a previous longitudinal analysis of bilateral foreign aid distribution, wealthy, developed

314 states were more likely to give financial aid to their former colonies and to states exhibiting

315 similar voting behaviors in the UNGA (Alesina \& Dollar, 2000). While these findings could 316 reflect geopolitical alliances that are highly correlated with former colonial relationships, the 317 authors also expressed concern that poorer states with smaller economies may try to maximize 318 the aid they receive by aligning their votes with their former colonizer's or other developed 319 states' interests (Alesina \& Dollar, 2000). If the authors “preferred interpretation" of their 320 findings is correct, "that donors favor their 'friends' in disbursing aid, and an observable 
321 manifestation of 'friendship' is the pattern of UN votes" (Alesina \& Dollar, 2000, p. 46), there

322 should be considerations that developed states could subvert poorer states' voting power within

323 the UNGA. analysis concluded poorer, less developed states with small economies lack power and are underrepresented in all UN organs, except for the UNGA body, where representation is required.

328 Wealthy, highly developed states, with large economies are overrepresented in all organs, usurp

329 power from poor states and experience few checks on their power due to a monopolization of

330 leadership positions. While the ECOSOC is the most pertinent organ to sustainable development

331 and environmental initiatives, it is important to consider the power structures within all organs

332 due to the interactions between organs. Further, date of admission to the UN does not appear to

333 be a contributing factor, since only five states have been admitted post January 1, 2000: Serbia

334 and Tuvalu (2000), Switzerland and Timor-Leste (2002), and South Sudan (2011). While Timor-

335 Leste and Tuvalu account for two of the eight (25\%) states classified as a LDC and SIDS, they

336 have both been members of the UN for at least 15 election cycles (UN, 2017c).

\section{Discussion}

The exploration of UN organ structure, and in particular the disparities in attainment of

339 leadership and more influential positions within the UN, suggests power differences may be

340 entrenched within the UN policy making system. Due to their positioning within the UN system,

341 economically powerful states may have more ability than poorer states to dictate regulatory

342 content in international policy-making negotiations to be congruent with their economic interests

343 and free-market values. Though their sovereign right, this maneuvering is often for self-gain and 
344 at the expense of the common good, which differentially impacts poorer states, and should be an

345 area of concern during the new UNCLOS negotiations.

346 The analyses also suggest economic power may be used by powerful states to exclude

347 LDCs and SIDS from participating in policy making processes. Though the UNFSA attempted to

348 increase equity by establishing an assistance fund to aid LDCs and SIDS in implementing the

349 agreement and participating in RFMOs and other regional policy-making processes (UN, 1995),

350 the fund has been depleted on multiple occasions (UN, 2015a), and appears to have been

351 depleted since at least October $4^{\text {th }}, 2016$ (Oceans and Law of the Sea in the General Assembly of

352 the United Nations, 2016) - hence poorer states' request for more stable funding in the

353 preparatory meeting. And, at the Eleventh Round of Informal Consultation of States Parties to

354 UNFSA, SIDS efforts to participate in a RFMO — the Western and Central Pacific Fisheries

355 Commission [WCPFC] —were described as being "blocked", despite continued rhetoric about

356 empowering developing states to participate in high seas fisheries management (UN, 2015a). To

357 encourage more developed, large economy states to contribute to a similar fund established

358 under the Port State Measures, it was determined donor states could earmark contributions for

359 specific projects (FAO, 2017). The 2015 UNGA resolution 69/292 agreeing to a new

360 international legally binding instrument under UNCLOS and establishing the preparatory

361 meetings also created a trust fund to assist LDCs in attending the preparatory meetings, but

362 contribution to the trust fund was voluntary (UN, 2015b).

363 To promote equity in the short-term, large economy states should be mandated to

364 contribute to currently voluntary funds to assist LDCs and SIDS participation in policy making

365 processes and to build their capacity for implementing new regulations and management tools-

366 a request continuously made by LDCs and SIDS (IISD, 2017). These funds could allow LDCs 
367 and SIDS to have prolonged and consistent engagement in low-level conference and preparatory

368 meetings where they may have more ability to influence a policy's substantive text, even if they

369 are compelled to vote with powerful countries in the UNGA as previously described, and to build

370 and/or strengthen regional partnerships. To center the interests of LDCs and SIDS, a relative and

371 objective administrative body (e.g., FAO) should have the authority to determine fund

372 distribution, based on standardized indicators of need which also account for relevance and

373 acuity of the policy or action item, rather than allowing developed states to earmark contributed

374 funds based on their own self-interests. This is particularly important when considering financial

375 aid to assist LDCs and SIDS in augmenting capacity with new technologies. Indeed, during the

376 fourth preparatory meeting, AOSIS, Togo, Ghana, PSIDS, and the Caribbean group sought to

377 establish a capacity-building fund to be accessed by SIDS and LDCs citing the need for long-

378 term sustainable funding due to the unsustainable nature of voluntary trust funds (IISD, 2017).

379 However, the United States, the European Union, Canada, and New Zealand opposed.

380 The efforts to initiate new negotiations also demonstrated the potential for consortiums of

381 non-governmental members (e.g., High Seas Alliance) to influence international policy making.

382 With deliberate consideration of how these consortiums can be inclusive and equitable, they may

383 present a more leverageable mechanism to create and accelerate new norms within international

384 policy making that can also center underrepresented knowledge in international policy

385 development. Many of these consortiums already feature prominent and reputable environmental

386 organizations - typically from developed countries - that may be perceived as experts by

387 international policy makers based on western standards of scientific merits. However, these

388 organizations can use their privilege to amplify and promote progress made by the consortium's 
smaller organizations. This may include advancing bottom-up approaches by recognizing and scaling up successful country-specific initiatives into regional and international action.

392 fisheries benefits distribution between high and low-income states based on fish dependence and 393 viable alternatives for meeting subsistence and development needs (e.g., food, nutrition, and

394 livelihoods) (Hankivsky, 2012). The establishment of marine protected areas and their level of

395 regulation around restricting catches will likely be one contentious area during treaty

396 negotiations, due to commercial fishing interests. Empirical findings and modeling suggest

397 closing the high seas could reduce inequalities in fisheries benefits distribution by $50 \%$ and

398 global annual profitability from fishing (mostly pocketed by industrialized states) will decrease

399 by approximately $1 \%$ for every $20 \%$ of the high seas closed in the short-term, with fishing

400 ultimately becoming more profitable over the long-term as stocks rebound (Sumaila et al., 2015;

401 White \& Costello, 2014). Additionally, in a study of 46 low-income and fish reliant countries,

402 models suggested $70 \%$ of the countries would experience increased catches after closing the high

403 seas (Teh et al., 2016).

\section{Implications for Social Work}

405 Though marine governance has historically been considered beyond social work's

406 purview, marine degradation resulting from ineffective governance disproportionately threatens

407 marginalized and vulnerable economies, communities, and individuals, making it a social justice

408 issue. Social work's person-in-environment perspective offers a unique and critically needed lens

409 through which to clearly identify the disparate impacts of physical environmental challenges like

410 marine degradation on social development, economic equity, and human rights. Making

411 international marine governance more just will require social work's disruption of entrenched 
412 power relations through greater attention to global policymaking and advocacy on behalf of

413 states marginalized within UN power structures.

$414 \quad$ This challenge has distinct implications for social work educators and scholars as well.

415 Growing curricular offerings in ecosocial work must place increased attention on the social

416 justice implications of the multitude of physical environmental challenges, as well as the global

417 power structures which govern environmental practices. Likewise, scholars of ecosocial work

418 and social policy must extend research on policy impacts to attend more deeply to the

419 policymaking process and its influence on the quality and content of policy solutions. Though

420 the UN is a body of politically appointed representatives, non-governmental advocacy

421 partnerships were influential in convening the renegotiations of UNCLOS. Social work research

422 identifying the disparate impacts of environmental degradation could provide an opportunity for

423 social workers to collaborate within these partnerships, and thus influence the governance of

424 marine ecosystems and other common-pool resources governed by the UN.

Conclusion

426 Disrupting potential systemic power structures in the UN, particularly in leadership positions,

427 could lead to marginalized states' increased inclusion and representation in policy-making

428 processes. By reducing inequities within the UN and subsequently high seas policy making,

429 potential outcomes may include stabilized and increased financial aid for marginalized states to

430 implement and adopt new regulations and technology; more equitable distribution of marine

431 resources' economic benefits; and, improved transparency and reduced stagnation in high seas

432 policy making. While this analysis was specific to UNCLOS, the statistics about UN organ

433 representation should also be understood in a larger context of social justice and inherent

434 weaknesses in UN structures requiring reforms to more equitably support vulnerable states. 


\section{Endnotes}

$436{ }^{1}$ Food and Agriculture Organization of the United Nations' (FAO) (1993) Agreement to

437 Promote Compliance with International Conservation and Management Measures by Fishing

438 Vessels on the High Seas; (1995) Code of Conduct for Responsible Fisheries; (2002)

439 International Plan of Action to Prevent, Deter and Eliminate Illegal, Unreported and Unregulated

440 Fishing; and (2009) Agreement on Port State Measures to Prevent, Deter, and Eliminate Illegal,

441 Unreported, Unregulated Fishing. United Nations' (1995) Fish Stocks Agreement and (2012)

442 Conference on Sustainable Development.

443

$444{ }^{2}$ LDCs and SIDS are both designations bestowed by the UN, based on indicators of

445 socioeconomic vulnerabilities. The SIDS designation also considers environmental

446 vulnerabilities resulting from unique island geographies. As such, not all SIDS are also classified 447 as a LDC. 


\section{References}

459 Alesina, A., \& Dollar, D. (2000). Who gives foreign aid to whom and why? Journal of Economic Growth, 5, 33-63.

461 Cullis-Suzuki, S., \& Pauly, D. (2010). Failing the high seas: A global evaluation of regional fisheries management organizations. Marine Policy, 34(5), 1036-1042.

463 Dieter, A. (2014). From harbor to high seas: An argument for rethinking fishery management systems and multinational fishing treaties. Wisconsin International Law Journal, 32(4),

Dreher, A., Nunnenkamp, P., \& Thiele, P. (2006). Does US aid buy UN General Assembly votes? A disaggregated analysis (Working Paper No. 138). Zurich: Swiss Federal Institute of Technology.

Editorial: Protect the high seas from harm. (2018). Nature, 553, 127-128.

470 Food and Agriculture Organization of the United Nations. (2016). The state of world fisheries and aquaculture: Contributing to food security and nutrition for all. Rome, Italy: FAO.

472 Food and Agriculture Organization of the United Nations. (2017). First meeting of the parties to the FAO Agreement on Port State Measures. Retrieved from http://www.fao.org/3/a-

475 Food and Agriculture Organization of the United Nations. (2018). The state of world fisheries and aquaculture: Meeting the sustainable development goals. Rome, Italy: FAO.

477 Galland, G., Rogers, A., \& Nickson, A. (2016). Netting billions: A global valuation of tuna.

478 Philadelphia, PA: Pew Charitable Trusts.

479 General Assembly of the United Nations, President of the $72^{\text {nd }}$ Session. (2017). Past presidents. Retrieved from https://www.un.org/pga/72/past-presidents/ 
481 Gjerde, K. M., Currie, D., Wowk, K., \& Sack, K. (2013). Ocean in peril: Reforming the management of global ocean living resources in areas beyond natural jurisdiction. Marine Pollution Bulletin, 74(2), 540-551. the deep seabed. Melbourne Journal of International Law, 4(2), 376.

Hankivsky, O. (Ed.). (2012). An intersectionality-based policy analysis framework.

Guntrip, E. (2003). The Common Heritage of Mankind: An adequate regime for managing international fisheries management (Policy options paper No. 9). Oxford, UK: GOC.

Global Ocean Commission. (2013). Improving accountability and performance in Vancouver, BC: Simon Fraser University.

High Seas Alliance. (2017). UN steps towards an implementing agreement. Retrieved from http://highseasalliance.org/sites/highseasalliance.org/files/hsa-timeline-update.pdf

Hornborg, A. (2009). Zero-sum challenges in conceptualizing environmental load displacement and ecologically unequal exchange in the world system. International Journal of Comparative Sociology, 50(3-4), 237-262.

International Court of Justice. (2017). Members. Retrieved from https://www.icjcij.org/en/members

International Institute for Sustainable Development. (2017). Summary of the $4^{\text {th }}$ Jurisdiction. Retrieved from http://enb.iisd.org/download/pdf/enb25141e.pdf

Kemp, S. P., \& Palinkas, L. A. (2015). Strengthening the social response to the human impacts of environmental change. Baltimore, MD: AASWSW. 
HIGH SEAS POLICY STAGNATION

504 Oceans and Law of the Sea in the General Assembly of the United Nations. (2016). Assistance

$505 \quad$ fund under Part VII of the agreement for the implementation of the provisions of the United Nations Convention on the Law of the Sea of 10 December 1982. Retrieved from https://www.un.org/depts/los/convention_agreements/fishstocktrustfund/fishstocktrustfun $\underline{\text { d.htm }}$

Stevenson, J. R., \& Oxman, B. (1994). The future of the United Nations Convention on the Law of the Sea. The American Journal of International Law, 88, 477-499.

511 Sumaila, U. R., Lam, V. W. Y., Miller, D. D., Teh, L., Watson, R. A., Zeller, D., ... Pauly, D. (2015). Winners and losers in a world where the high seas is closed to fishing. Scientific Reports, 5(8481), 1-6.

514 Teh, L. S., Lam, V. W., Cheung, W. W., Miller, D., Teh, L. C., \& Sumaila, U. R. (2016). Impact on high seas closure on food security in low income fish dependent countries. PloS ONE, 11(12), e0168529. doi:10.1371/journal.pone.0168529

Teh, L.S., \& Sumaila, U. R. (2013). Contribution of marine fisheries to worldwide employment. Fish and Fisheries, 14, 77-88.

519 United Nations. (1945). Charter of the United Nations and Statute of the International Court of Justice. Signed at San Francisco, California, 26 June 1945, entered into force 24

522 United Nations. (1982). United Nations Convention on the Law of the Sea of 10 December 1982. 
525 United Nations. (1995). Fish Stocks Agreement. Retrieved from

526 https://www.un.org/Depts/los/convention_agreements/convention_overview_fish_stocks.

$527 \quad \underline{h t m}$

528 United Nations. (2015a). Eleventh round of informal consultations of States parties to the agreement for the implementation of the provisions of UNCLOS: Report. Retrieved from https://www.un.org/Depts/los/convention_agreements/fishstocksmeetings/icsp11_final_fs

United Nations. (2016). Main organs. Retrieved from https://www.un.org/en/sections/about-

United Nations. (2015b). United Nations General Assembly Resolution 69/292. Development of a.pdf an internationally legally binding instrument under the United Nations Convention on the Law of the Sea on the conservation and sustainable use of marine biological diversity of areas beyond national jurisdiction. Retrieved from https://undocs.org/en/a/res/72/249

542 United Nations General Assembly Seventy-Second Session. (2017b). $76^{\text {th }}$ meeting coverage: $\underline{\text { un/main-organs/ }}$

United Nations General Assembly Seventy Second Session. (2017a). 63 $3^{\text {rd }}$ and $64^{\text {th }}$ meetings coverage: Adopting two texts on oceans, seas, General Assembly also tackles sustainable management, conservation of marine life beyond national jurisdiction. Retrieved from https://www.un.org/press/en/2017/ga11985.doc.htm Concluding main part of seventy-second session, General Assembly adopts $\$ 5.397$ billion budget for 2018-2019, as recommended by fifth committee. Retrieved from https://www.un.org/press/en/2017/ga11997.doc.htm

United Nations. (2017c). Member states. Retrieved from https://www.un.org/en/member-states/ 
547 U. N. Economic and Social Council. (2017). Members. Retrieved from

$548 \quad$ https://www.un.org/ecosoc/en/content/members

549 U. N. Office of the High Representative for the Least Developed Countries, Landlocked

550 Developing Countries and Small Island Developing States (UN-OHRLLS). (2017). Least

551 developed countries. Retrieved from http://unohrlls.org/about-ldcs/

552 U. N. Secretary-General. (n.d.). Former secretaries-general. Retrieved from https://www.un.org/ $553 \mathrm{sg} / \mathrm{en} /$ content/former-secretaries-general

554 U. N. Security Council. (n.d.). Members. Retrieved from https://www.un.org/securitycouncil/ $555 \quad$ content/current-members

556 Visbeck, M., Kronfeld-Goharani, U., Neumann, B., Rickels, W., Schmidt, J., van Doorn, E., 557 ... Proelss, A. (2014). A sustainable development goal for the ocean and coasts: Global ocean challenges benefit from regional initiatives supporting globally coordinated solutions. Marine Policy, 49, 87-89.

560 White, C., \& Costello, C. (2014). Close the high seas to fishing? PLoS Biology, 12(3), e1001826. doi:10.1371/journal.pbio.1001826

562 World Bank. (2017). World Bank open data. Retrieved from https://data.worldbank.org 